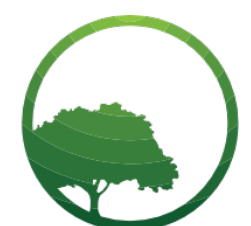

Business \& Social Science IJRBS

\section{Research in Business and Social Science}

IJRBS Vol 7 No 1, ISSN: 2147-4478

Contents available at www.ssbfnet.com/ojs

\title{
Determinant Factors Influencing Impulse Buying Behavior of Turkish Customers in Supermarket Setting
}

\author{
Aysen Akyuz
}

Assoc. Prof. Department of Communication, Istanbul Medipol University, Istanbul, Turkey

\begin{abstract}
Impulse buying is a common phenomenon of consumption today and its getting great attention from consumer researchers as well as marketers. It is important for companies to have a good understanding of factors triggering impulse buying. The main aim of this study is to identify the determinants influencing Turkish consumers' impulse buying behavior in supermarkets. 593 surveys were taken into analysis which were collected between the dates 5-10 December, 2017. Regression analysis, t-test and ANOVA test were conducted to test the hypotheses. While some independent variables such as sales promotion and credit card usage found to be the affecting factors of impulse buying; variables such as income level is found to have no relation with impulse purchasing.
\end{abstract}

Key words : Impulse Buying, Determinant Factors

JEL classification: $\mathrm{H} 2 \mathrm{O}, \mathrm{H} 26, \mathrm{H} 30$

\section{Introduction}

Impulse buying has become a widespread and distinct phenomenon and has received increasing attention from consumer researchers and theorists. An impulse buy is a purchase made unscheduled or spontaneously, without thought. The consumer is exposed to a stimulus and decides to buy it. The purchasing decision for the consumer is instantaneous and the individual acts without thinking about the consequences of such a purchase. Nowadays impulse buying behavior has become the usual behavior. It is therefore important for both consumers and marketers to know the reasons that lead to unplanned shopping.

Kollat and Willett states that (1969) altough impulse purchasing takes place in many retail outlets; it is most commonly studied in supermarket settings. Many supermarket executives use impulse buying as a standard for decisions about space location, etc. Certain store layouts or product locations thought to be more consistent with impulse buying compared with the others. This study will explore the impacting factors leading impulse purchasing in supermarket environment. 
This study is organized as follow: Following the introduction part of this paper, Impulse buying with existing literature has been outlined. Statistical analysis and research methods in this study are explained in section three and finally the results and implications of the reseach have been assessed for further studies.

\section{Literature Review}

\section{Impulse Buying}

The impulse buying process starts with the product awareness. Individuals begin to browse products without intending to purchase, and at the same time they are exposed to stimuli and feel desire to purchase. In terms of the consumer purchasing process, the consumer becomes aware of the need when exposed to stimulus and goes directly to the purchasing path, bypassing the information search or evaluation of alternatives stages. Naturally, the post purchase evaluation step will result in satisfaction or dissatisfaction. Impulse buyers are motivated to satisfy their pleasures urgently, and this cannot be categorized for one specific product category. So impulsive buying can be seen in several product categories such as jewelry or grocery items.

Within the decision process models, perhaps the most widely known and accepted is the model, developed by Engel, Kollat and Blackwell in late 1960s. Later the model has gone under several revisions. The latest version of the model which is called "Consumer Decision Process Model-CDPM) developed with the contribution of Miniard, comprises the following stages: need recognition, search for information, evaluation of alternatives, purchase, consumption and post-consumption evaluation as well as divestment. In order to fulfill the needs that the consumer has, the consumer goes through the indicated stages. According to Badgaiyan, et al. (2016), the early model did not consider the emotional process and therefore did not explain impulse buying. But with their study undertaken in 2006, Blackwell, Miniard and Engel (2006) defined Impulse buying as a limited problem-solving decision. Limited problem-solving decision means that in the decisionmaking process the search for information and the pre-purchase evaluations are limited.

Rook (1987, p. 191) suggests impulse buying occurs: "when a consumer experiences a sudden, often persistent urge to buy something immediately. The impulse to buy is hedonically complex and may stimulate emotional conflict. Also, impulse buying is prone to occur with diminished regard for its consequences ( $p$. 191)." Beatty and Ferrell (1998, p. 170) extended Rook's definition of impulse buying to "a sudden and immediate purchase with no pre-shopping intentions either to buy the specific product category or to fulfill a specific buying task. The behavior occurs after experiencing an urge to buy and it tends to be spontaneous and without a lot of reflection. It does not include the purchase of a simple reminder item, which is an item that is simply out-of-stock at home." According to Cheng et al. (2013) impulse purchasing is not about solving a preexisting problem or searching for a good to cater a predetermined need; instead it involves the pleasure that responds to the passion to purchase.

Kollat and Willet (1969) state that, there are two conflicting opinions about why unplanned buying occurs. These are the exposure to in-store stimuli and the customer commitment hypotheses. The exposure hypothesis states that since shoppers use product assortments and other in-store stimuli to remind them of their shopping needs and make some buying decisions in the store and/or, in store promotions make the consumers recognize different and new ways of catering the needs, exposure to in-store stimuli result in impulse buying behavior. The authors emphasize that contrary to what seems to be accepted by many marketers and academicians, increase in product exposure does not always end with increased impulse purchasing. On the other hand, the customer commitment hypothesis points out that unplanned purchasing are attributable, in part, to incomplete measure of purchase plans.

According to Ling and Yazdanifard (2015), there are four characteristics to further explain impulsive purchase. Above all else, impulse buying is an unplanned buying, which people do the purchasing without making any plan beforehand. Secondly, impulse buying is a consequence of exposure to the stimulus, in which individuals buying rashly is activated by the external stimulus such as the cost or design of the product. Thirdly, it is a prompt nature of behavior in which individuals buy without considering the information seek, alternative evaluation and outcomes of the purchasing; people buy with the result of sudden and strong urge 
or desire. Lastly, such purchase, makes individuals experience emotional or cognitive responses such as guilt.

According to Rook and Fisher (1995), some people have a higher tendency to buy on impulse than others. These people are likely to be more spontaneous in their buying behavior compared to others. Also, they tend to think more irrational while shopping and react immediately on their buying impulses. Lastly, they can be defined as more active in their shopping behavior since they frequently engage in impulse purchasing than people who are demonstrate less impulsive behavior. Cho et al. (2014) states that it is paramount for marketers to understand the unplanned buying behavior in order to devise marketing strategies and drive tactics from these strategies.

\section{Impacting Factors of Impulse Buying and Research Hypotheses}

Kollat and Willet (1967) state that consumers' demographics has an impact on impulsive behavior.

Dittmar et al., (1995) found that gender has an influence on purchase of a good with a sudden and irresistible urge to buy. According to their study women tend to buy symbolic and self-expressive goods whereas men prefer to buy items reflecting their independence and activeness such as instrumental and leisure items. According to Mburu (2010), men generally do not like shopping as women do. And this could lead them to impulse buy less. Conversely, Cobb and Hoyer (1986) indicate that, women usually prefer to make planning before shopping and therefore men make more impulse purchases than women.

Age (Helmers et al., 1995; Wood, 1998) also, has an impact on impulse buying. Kacen and Lee (2002), for example pointed out that young people have found to be engaged in impulse purchasing compared to elders and demonstrate less self-control. Indicated studies support that people under 35 years of age are more prone to impulse purchase. Also, in a study conducted by (Mai et al., 2003), it was shown that age of buyers from 18 to 40 are generally impulsive.

Education is another influencing factor of impulse buying. Educated people make less impulse purchase and do planned shopping. On the other hand, people with lower educational qualification might indulge in more impulse buying (Wood, 1998). In their study, Rana and Tirthani (2012), find out that there is negative relationship between education and impulse buying behavior of consumers.

Income is another variable of impulse buying. As noted, (Dittmar et al., 1996), people with high income (also having high disposable income) can be assumed to be purchasing more impulsively than the people with low disposable income. From a socioeconomic point of view, individuals with relatively low levels of household income tend to enjoy immediate indulgence such as day-to-day savings as opposed to delay gratification. Internal, personal-related factor like educational experience influences the act of impulse buying (Wood, 1998)

About the relationship and marital status Geetha and Bharadhwaj (2016) point out that single people, since they do not have much responsibilities as married people do, would spend more impulsively. Married people on the other hand have dependents (their children) and therefore they have restraints on the resources available. Sangalang et.al. (2017), conversely, found that impulse buying is undertaken by married persons as compared to single in their research. We propose,

H1. Consumers' impulse buying in supermarkets is significantly different depending upon their (a) genders, (b) ages, (c) education levels, (d) income levels, (e) marital status.

Zhou and Gu (2015) state that the price-based promotions have been increased in the last years because of its ability to stimulate the sales and the amount of money or percentage-off based price presentation has a significant impact on impulse purchasing. It is also mentioned that, they from a retailer's point of view, priceoff promotions are used to increase market share and to get trial of product by non-users. Price reduction has a significant effect on unit sales (Blattberg et al.,1981). As pointed out by Stilley et al., (2010) and Peck and Childers, (2006), in-store promotions also have a positive impact on impulse purchasing since they might remind the forgotten needs to the customers. As Pawar et al. write (2016), instore promotions or events include a variety of promotional vehicles such as on-pack promotions (buy 1 get 1 free), in-store demonstrations, product sampling and etc. Promotions encourage shoppers through the decision-making 
process, by raising awareness and interest of products, and also converting the interest into actual purchase. And this would increase impulse buying behavior. Accordingly, we propose:

H2: Sales Promotion (sample, discount etc.) is positively related to impulse buying behavior.

Impulsive buyers have been shown to have more credit cards than other consumers (O'Guinn \& Faber,1989). According to Karbasivar and Yarahmadi (2011), the use of credit card is one of the factors to cause consumer purchase impulsively. As customers do not have to pay instantly, they are more likely to overspend and purchase impulsively. Besides, credit card owners are found to be less conscious on the price of goods and this can cause them to buy goods with higher prices (Tokunaga, 1993; Deshpande and Krishnan, 1980; as cited in Karbasivar \& Yarahmadi,2011). Thus, following hypothesis is formulated:

H3: There is a positive relationship between credit card usage and impulse buying.

Previous research (Rook, 1987; Rook \& Gardner, 1993: Beatty and Ferrell,1998, Kacen, 1998; Raghunathan and Pham, 1999) shows that impulse buying occurred under both positive and negative moods. Similarly, Rook and Gardner (1986) have demonstrated that a consumer's mood impacts the amount of money spent on impulse purchases. As noted by, Kacen and Lee (2002) consumers' positive mood is shown to be more important to the impulse buying behavior than negative, while impulse buying happens under both positive and negative moods. Conversely, Rook (1986), states that consumers engage in impulse buying behavior to acquire the things that they desire and to feel good or transform a negative mood state. Berneman and Heeler (1986) found that shoppers compensate for negative mood states and complement positive mood states through shopping activities. Therefore, following hypotheses can be proposed,

H4: (a) There is a positive relationship between positive mood and impulse buying.

(b) There is a positive relationship between negative mood and impulse buying.

\section{Research and Methodology}

Questionnaire was used in this study in order to collect data. It was prepared in a single form with a total of five sections. During the preparation of the survey questions, care had been taken in terms of being clear and easily understood by respondents. For the convenience in answering the questions and also in the analysis, questions were prepared as the form of closed-ended, dual choice and due to 5-point Likert scale. Participants assessed the appropriateness of the statements due to 5-point Likert scale. The data collection phase of the study was performed between 5 December - 10 December 2017.

The selection of those participating in the questionnaire was made by using simple sampling method. The sample of the study is drawn from social media users. Within the above-mentioned period, the respondents were reached via Facebook and Instagram, and it was requested to answer the questionnaire by giving link to Webanketa site where the questionnaire was hosted. IP protected limitation was arranged in order to enable the completion of the questionnaire for only once by each user. Within the time specified above, a total of 610 questionnaires were filled but 17 of them were not taken into account because of being incomplete or filled incorrectly and analyzes were performed on 593 surveys.

The answers given to the adjectives were carried out by granting 5 points to the choice "I strongly agree" and by granting 1 point to the choice "I strongly disagree". In the first section of the questionnaire, there were 6 questions regarding the demographics and the user profile of the respondent. In the second part, 12 questions were asked regarding the impulse buying. In the third part there were 3 questions related to sales promotion variable; fourth and fifth parts covered 2 questions for each to determine the credit card usage and positive and negative mood variable. Survey questions are adapted from the studies of Beatty and Ferrell (1998), Youn and Faber, (2000), Badgaiyan et al (2016), Cho et al. (2014).

\section{Findings}

SPSS 22.0 Statistical package program is used for the statistical analyses. When the data is assessed, descriptive statistical methods are used. When the data is assessed, descriptive statistical methods are used. Pearson Correlation analysis is used in order to detect the relations among variables. Regression analysis 
Akyuz / International Journal of Research in Business and Social Science,

Vol 7 No 1, 2018 ISSN: 2147-4486

is used in order to examine the effect of independent variables on the dependent variable. One-way ANOVA is used to determine whether there are any statistically significant differences between the means of groups.

Table 1: Demographic Profile of the Sample

\begin{tabular}{|c|c|c|c|}
\hline & Groups & Frequency(n) & Percentage (\%) \\
\hline \multirow{5}{*}{ Age } & $19-29$ & 214 & 36,1 \\
\hline & $30-39$ & 193 & 32,5 \\
\hline & $40-49$ & 142 & 23,9 \\
\hline & 50 and above & 44 & 7,4 \\
\hline & Total & 593 & 100,0 \\
\hline \multirow{3}{*}{ Gender } & Women & 410 & 69,1 \\
\hline & Men & 183 & 30,9 \\
\hline & Total & 593 & 100,0 \\
\hline \multirow{7}{*}{ Income Level (TL-Turkish Lira) } & $1000 \mathrm{TL}$ and below & 55 & 9,3 \\
\hline & 1001-2000 TL & 129 & 21,8 \\
\hline & 2001-3000 TL & 119 & 20,1 \\
\hline & $3001-4000 \mathrm{TL}$ & 89 & 15,0 \\
\hline & $4001-5000 \mathrm{TL}$ & 76 & 12,8 \\
\hline & $5001 \mathrm{TL}$ and above & 125 & 21,1 \\
\hline & Total & 593 & 100,0 \\
\hline \multirow{6}{*}{ Education level } & \begin{tabular}{|ll}
$\begin{array}{l}\text { Primary } \\
\text { degree }\end{array}$ & \\
\end{tabular} & 12 & 2,0 \\
\hline & $\begin{array}{ll}\text { High } & \text { school } \\
\text { graduate } & \end{array}$ & 120 & 20,2 \\
\hline & Bachelor's degree & 349 & 58,9 \\
\hline & Master's degree & 73 & 12,3 \\
\hline & Doctoral Degree & 39 & 6,6 \\
\hline & Total & 593 & 100,0 \\
\hline \multirow{7}{*}{ Profession status } & House wife & 86 & 14,5 \\
\hline & Student & 61 & 10,3 \\
\hline & \begin{tabular}{|ll} 
Private & sector \\
employee &
\end{tabular} & 225 & 37,9 \\
\hline & $\begin{array}{ll}\text { Public } & \text { sector } \\
\text { employee } & \\
\end{array}$ & 87 & 14,7 \\
\hline & Self-employment & 62 & 10,5 \\
\hline & Other & 72 & 12,1 \\
\hline & Total & 593 & 100,0 \\
\hline \multirow{4}{*}{ Marital status } & Single & 244 & 41,1 \\
\hline & Married & 323 & 54,5 \\
\hline & Other & 26 & 4,4 \\
\hline & Total & 593 & 100,0 \\
\hline
\end{tabular}


Table 2: t-test and ANOVA

\begin{tabular}{|c|c|c|}
\hline Demographics & $\mathbf{n}$ & Impulse buying \\
\hline $\begin{array}{l}\text { Age } \\
19-29 \\
30-39 \\
40-49 \\
50 \text { and above } \\
F= \\
p= \\
M W U=\end{array}$ & $\begin{array}{l}214 \\
193 \\
142 \\
44\end{array}$ & $\begin{array}{l}\text { Mean } \pm \text { SD } \\
3,032 \pm 0,711 \\
2,946 \pm 0,847 \\
2,881 \pm 0,720 \\
2,667 \pm 0,897 \\
3,112 \\
0,026 \\
1>4,2>4(p<0.05)\end{array}$ \\
\hline $\begin{array}{l}\text { Gender } \\
\text { Women } \\
\text { Men } \\
t= \\
p=\end{array}$ & $\begin{array}{l}410 \\
183\end{array}$ & $\begin{array}{l}\text { Mean } \pm \text { SD } \\
2,994 \pm 0,789 \\
2,823 \pm 0,743 \\
2,481 \\
0,013\end{array}$ \\
\hline $\begin{array}{l}\text { Income Level (Turkish Lira) } \\
1000 \mathrm{TL} \text { and below } \\
1001-2000 \mathrm{TL} \\
2001-3000 \mathrm{TL} \\
3001-4000 \mathrm{TL} \\
4001-5000 \mathrm{TL} \\
5001 \mathrm{TL} \text { and above } \\
\mathrm{F}= \\
p=\end{array}$ & $\begin{array}{l}55 \\
129 \\
119 \\
89 \\
76 \\
125\end{array}$ & $\begin{array}{l}\text { Mean } \pm \text { SD } \\
2,845 \pm 0,694 \\
2,876 \pm 0,792 \\
3,044 \pm 0,758 \\
2,928 \pm 0,788 \\
2,989 \pm 0,842 \\
2,932 \pm 0,773 \\
0,834 \\
0,526\end{array}$ \\
\hline
\end{tabular}

\begin{tabular}{lll}
\hline Education Level & & Mean \pm SD \\
\cline { 2 - 2 } Primary education & 12 & $2,705 \pm 1,030$ \\
High school & 120 & $2,770 \pm 0,787$ \\
University & 349 & $2,968 \pm 0,762$ \\
Master's degree & 73 & $2,970 \pm 0,740$ \\
Doctoral degree & 39 & $3,245 \pm 0,783$ \\
$\mathrm{~F}=$ & & 3,398 \\
$\mathrm{p}=$ & & 0,009 \\
MWU= & $5>1,3>2,5>2,5>3(\mathrm{p}<0.05)$ \\
& & \\
\hline Marital Status & & Mean $\pm \mathrm{SD}$ \\
Single & 244 & $3,024 \pm 0,774$ \\
Married & 323 & $2,872 \pm 0,773$ \\
Other & 26 & $3,011 \pm 0,834$ \\
$\mathrm{~F}=$ & & 2,776 \\
$\mathrm{p}=$ & & 0,063 \\
& & \\
\hline
\end{tabular}

Gender: According to the results of the t-test conducted to determine whether participants' mean scores of impulse buying scores shows a significant difference, it is found out that there is a significant difference between the group's means $(t=2.481, p=0.013<0.05)$. Women's impulse buying behavior scores $(x=$ $2,994)$ are higher than men's $(x=2,823)$. Accordingly, H1a is supported. 
Age: One-way analysis of variance (ANOVA) is conducted to determine whether participants' mean scores of impulse shopping behavior show a significant difference in terms of age variable. The result is significant $(F=3,112 ; p=0.026<0.05)$. The PostHoc test is used to determine which group originated the difference. According to this; impulse buying behavior scores $(3,032 \pm 0,711)$ for those aged 19-29 is higher than impulse shopping behavior scores $(2,667 \pm 0,897)$ for those aged 50 and over. Impulse buying behavior behavior scores $(2,946 \pm 0,847)$ for those aged 30 -39 is higher than impulse buying behavior $(2,667 \pm 0,897)$ for those aged 50 and over. Thus, $\mathrm{H} 1 \mathrm{~b}$ is supported.

Education level: One-way analysis of variance (ANOVA) is conducted to determine whether participants' mean scores of impulse shopping behavior show a significant difference in terms of education level variable. The result is significant $(F=3,398 ; p=0.009<0.05)$. The PostHoc test is used to determine which group originated the difference. Accordingly; individuals with doctorate degree $(3,245 \pm 0,783)$ demonstrate impulse buying behavior more than people with primary education degree $(2,705 \pm 1,030)$ and university graduates $(2,968 \pm 0,762) . \mathrm{H} 1 \mathrm{c}$ is supported.

Income Level: There is no significant difference between the groups in terms of income level $(p>0.05)$. Accordingly, $\mathrm{H} 1 \mathrm{~d}$ is not supported.

Marital status: There is no significant difference between the groups in terms of marital status $(p>0.05)$. Therefore, $\mathrm{H} 1 \mathrm{e}$ is not supported.

Table 3: Correlation Analysis

\begin{tabular}{|c|c|c|c|c|c|c|c|}
\hline & 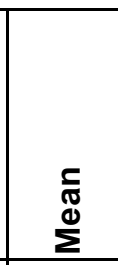 & 只 & 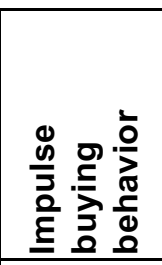 & 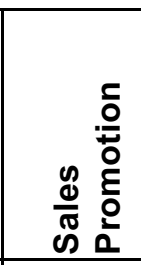 & 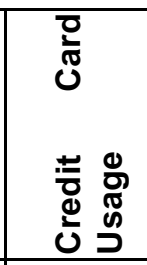 & 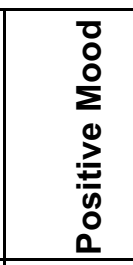 & 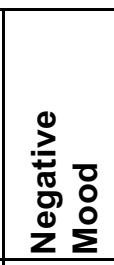 \\
\hline Impulse buying behavior & 2,941 & 0,778 & 1,000 & & & & \\
\hline Sales Promotion & 2,588 & 0,926 & $0,510^{* *}$ & 1,000 & & & \\
\hline Credit Card Usage & 3,247 & 1,179 & $0,302^{* *}$ & $0,260^{* *}$ & 1,000 & & \\
\hline Positive Mood & 2,780 & 1,088 & $0,368^{* *}$ & $0,303^{* *}$ & $0,250^{* *}$ & 1,000 & \\
\hline Negative Mood & 2,620 & 1,196 & $0,478^{* *}$ & $0,325^{\star *}$ & $0,201^{* *}$ & $0,147^{* *}$ & 1,000 \\
\hline
\end{tabular}

${ }^{*}<0,05 ;{ }^{* *}<0,01$

The level of "impulse buying" of survey participants is found out to be moderate $(2,941 \pm 0,778)$; "Sales promotion" level is weak $(2,588 \pm 0,926)$; "Credit card usage" level is moderate $(3,247 \pm 1,179)$; The level of "positive mood" is moderate $(2,780 \pm 1,088)$; and "Negative mood" level is found to be moderate $(2,620 \pm$ 1,196); respectively.

There is a significant positive correlation between the sales promotion and impulse buying behavior $(r=0.51$; $p=0,000<0.05)$. There is a weak positive correlation between credit card usage and impulse buying $(r=$ $0.302, p=0,000<0.05$ ). There is a weak positive correlation between credit card usage and sales promotion $(r=0.26 ; p=0,000<0.05)$. There is a significant positive correlation between positive mood and impulse buying $(r=0.368 ; p=0,000<0.05)$. There is a significant positive correlation between positive mood and sales promotion $(r=0.303, p=0,000<0.05)$. There is a very weak positive correlation between positive mood and use of credit card $(r=0.25 ; p=0,000<0.05)$. There is a significant positive correlation between negative mood and impulse buying behavior $(r=0.478, p=0,000<0.05)$. There is a significant positive correlation between negative mood and sales promotion $(r=0.325 ; p=0,000<0.05)$. There is a very weak positive correlation between negative mood and credit card usage $(r=0.201 ; p=0.000<0.05)$. There is a very weak positive correlation between negative mood and positive mood $(r=0.147 ; p=0,000<0.05)$. 
Akyuz / International Journal of Research in Business and Social Science,

Vol 7 No 1, 2018 ISSN: 2147-4486

Table 4: Regression Analysis

\begin{tabular}{|l|l|l|l|l|l|l|l|}
\hline Dependent Variable & Independent Variable & $\mathbf{B}$ & $\mathbf{t}$ & $\mathbf{p}$ & $\mathbf{F}$ & Model (p) & $\mathbf{R}^{\mathbf{2}}$ \\
\hline \multirow{4}{*}{ Impulse Buying Behavior } & Constant & 1,079 & 10,938 & 0,000 & & & \\
\cline { 2 - 6 } & Sales Promotion & 0,267 & 9,096 & 0,000 & & & \\
\cline { 2 - 6 } & Credit Card Usage & 0,069 & 3,140 & 0,002 & 107,343 & 0,000 & \multirow{2}{*}{0,418} \\
\cline { 2 - 6 } & Positive Mood & 0,142 & 5,921 & 0,000 & & & \\
\cline { 2 - 5 } & Negative Mood & 0,212 & 9,728 & 0,000 & & & \\
\hline
\end{tabular}

The regression analysis which is made to determine the relation among sales promotion, credit card usage, positive mood, negative mood and impulse buying behavior is found statistically significant ( $F=107,343$; $p=0,000<0.05$ ). It is seen that the relationship of it with the variables of sales promotion, credit card usage, positive mood and negative mood as the determinant of impulse buying is very strong in terms of explanatory power $(R 2=0,572)$. Sales promotion $(~(=0,267)$, credit card usage $(\beta=0,069)$, positive mood $(\beta=0,142)$ and negative mood $(\beta=0,212)$, increase impulse buying level. Therefore, we can state that hypotheses, $\mathrm{H} 2, \mathrm{H} 3$, $\mathrm{H} 4 \mathrm{a}$ and $\mathrm{H} 4 \mathrm{~b}$ are supported.

\section{Conclusion}

In a world with a fierce competition, it is paramount for companies to understand consumer behavior. Impulse buying is a kind of shopping done immediately and without thinking much. Although this behavior exists in every type of retail, such as clothing, jewelry, impulse buying behavior in supermarkets has been explored within our study. The study is believed to make significant contribution in terms of expanding and complementing the current marketing knowledge.

An empirical analysis was undertaken to explore what triggers impulse buying behavior of Turkish consumers in supermarket setting. The research reveals that sales promotion, credit card usage and both negative and positive moods impact the impulse buying behavior positively, whereas demographic variables, age, gender, education level are found to be statistically significantly different while income level and marital status showed no significance difference. It is believed that the findings can lead a supermarket retailer to have an understanding of the factors affecting impulse behavior; and devise plans accordingly.

There are also some certain limitations of the study. Future work may include some other variables such as the influence of salespeople, time, physical surrounding of the store, etc. Besides, data collection in subsequent researches can be done for different store formats or with a wider number of participants.

\section{References}

Applebaum, W. (1951). "Studying Consumer Behavior in Retail Stores". Journal of Marketing, 16, 172- 178.

Alauddin, Hossain, M., Ibrahim, Hoque, A. (2015). Perceptions of Consumer Impulse Buying Behavior in the Super Store: A Case Study of Some Selected Super Store in Bangladesh. Asian Social Science, 11 (9), 68-76.

Badgaiyan, A.J., Verma, A., Dixit, S. (2016). Impulsive buying tendency: Measuring important relationships with a new perspective and indigenous scale. IIBM Management Review, 28 (4), 186-199.

Beatty, S. E., \& Ferrell, M. E. (1998). Impulse Buying: Modeling Its Precursors. Journal of Retailing, 74(2), 169-191.

Berneman, C., Reeler, R. (1986). Shoppers' Mood and Purchases, Paper presented at ASAC Conference, June 2-5, Vancouver, BC, Canada.

Blackwell, R., Miniard, P., \& Engel, J. (2006). Consumer Behavior. Thomson-South Western Company.

Blattberg, R. C., Eppen, G. D., and Lieberman, J. (1981). A Theoretical and Empirical Evaluation of Price Deals in Consumer Nondurables, Journal of Marketing 45 (Winter), 116-129. 
Cheng, Y., Chuang, S., Wang, S. Kou, S. (2013). The effect of companion's gender on impulsive purchasing: the moderating factor of cohesiveness and susceptibility to interpersonal influence. Journal of Applied Social Psychology, 43, pp. 227-236.

Cho, J., Ching, G.S. Luong, T. (2014). Impulse buying behavior of Vietnamese consumers in supermarket setting. International Journal of Research Studies in Management, 3(2),33-50.

Cobb, C. J. and Hoyer W. D. (1986). Planned Versus Impulse Purchase Behavior. Journal of Retailing, 62, 67-81.

Deshpande, R., Krishnan, S. (1980). Consumer Impulse Purchase and Credit Card Usage: an Empirical Examination Using the Log Linear Model", in NA - Advances in Consumer Research Volume 07, eds. Jerry C. Olson, Ann Abor, MI: Association for Consumer Research, 792-795.

Dittmar, H., Beattie, J. Friese, S. (1995). Gender Identity and Material Symbols: Objects and Decision Considerations in Impulse Purchases. Journal of Economic Psychology, 16 (3), 491-511.

Engel, J. F., Kollat, D. T., and Blackwell, R. D. (1968) Consumer Behavior, New York: Holt, Rinehart and Winston.

Geetha, M., Bharadhwah, S. (2016). Impulse Buying Behavior in India-An overview. Asian Journal of Business Research, 6(1), 49-66.

Helmers K.F., Young S.N., Pihl R.O. (1995). Assessment of measures of impulsivity inhealthy male volunteers, Personality and Individual Differences, 19(6), 927-35.

Kacen, J.J. (1998). Retail therapy: Consumers' shopping cures for negative moods. Advances in Consumer Research, 25, 75-87.

Kacen J.J., Lee J.A. (2002). The influence of culture on consumer impulsive buying behavior, Journal of Consumer Psychology, 12(2), 163-76.

Karbasivar, A., \& Yarahmadi, H. (2011). Evaluating effective factors on consumer impulse buying behavior. Asian Journal of Business Management Studies, 2(4), 174-181.

Kollat, D.T., Willet, R.P. (1967). Customer Impulse Purchasing Behavior. Journal of Marketing Research, 4 (1), 21-31.

Kollat, D.T., Willet, R.P. (1969). Is Impulse Purchasing Really a Useful Concept for Marketing Decisions? Journal of Marketing, 33, 79-83.

Ling, L.P., Yazdanifard, R. (2015). What Internal and External Factors Influence Impulsive Buying Behavior in online Shopping? Global Journal of Management and Business Research, 15 (5), 25-32.

Mai, N. T. T., Jung, K., Lanz, G. and Loeb, S.G. (2003). An exploratory investigation into impulse behavior in a transactional economy: a study of urban consumers in Vietnam, Journal of International Marketing, 11 (2), 13-35.

Mburu, P.T. (2010). Impulse buying behavior on country of origin products by expatriates and its marketing implications. International Journal of Marketing and Management Research, 1(1), 37-54.

O'Guinn, Thomas C., \& Faber, Ronald J. (1989). Compulsive buying: A phenomenological exploration, Journal of Consumer Research, 16, 147-157.

Pawar, A.P., Shastri, D., Raut, U.R. (2016). In-store sampling and impulsive buying behavior: An empirical approach. Journal of Applied Research, 2(4), 304-307.

Peck, J., Childers, T.L. (2006). If I touch it I have to have it: Individual and environmental influences on impulse purchasing, Journal of Business Research, 59 (6), 765-769.

Raghunathan, R., Pham, M.T. (1999). All negative moods are not equal: Motivational influences of anxiety and sadness on decision making. Organizational Behavior and Human Decision Processes, 79(1), $56-77$. 
Rana, S. and Tirthani, J. (2012). Effect of Education, Income and Gender on Impulsive Buying Among Indian Consumer an Empirical Study of Readymade Garment Customers". Indian Journal of Applied Research, 1 (12) 145-146.

Rook, D. W. (1987). The Buying Impulse. Journal of Consumer Research, 14, 189-199.

Rook, D.W., Fisher, R.J. (1995). Normative Influences on Impulsive Buying Behavior. Journal of Consumer Research, 22 (3), 305-313.

Rook, D. W. and Gardner M. P. (1993). In the Mood: Impulse Buying' Affective Antecedent, pp. 1-28 in Janeen Arnold-Costa and Russell W. Belk (Eds.), Research in Consumer Behavior, Vol. 6, Greenwich, CT: JAI press.

Sangalang, R.A., Siochi, J., Plaza, M. (2017). Factors Influencing Consumers' Impulse Buying Behavior in the Fifth District of Cavite. Presented at the DLSU Research Congress 2017, De La Salle University, Manila, Philippines, June 20 to 22, 2017.

Stilley, K., Inman, J., \& Wakefield, K. (2010). Planning to Making Unplanned Purchases? The Role of InStore Slack in Budget Deviation, Journal of Consumer Research, 37, 264-278

Tokunaga, H. (1993). The use and abuse of consumer credit: Application of psychological theory and research. Journal of Economic Psychology, 14, 285-316.

Wood, M. (1998). Socio-economic status, delay of gratification, and impulse buying. Journal of Economic Psychology, 19, 295-320.

Youn, S., Faber J.R. (2000) "Impulse Buying: Its Relation to Personality Traits and Cues", in NA - Advances in Consumer Research Volume 27, eds. Stephen J. Hoch and Robert J. Meyer, Provo, UT: Association for Consumer Research, Pages: 179-185.

Zhou, H. Gu, Z. (2015). The effect of different price presentations on consumer impulse buying behavior: The role of anticipated regret, American Journal of Industrial and Business Management, 5, 27-36. 